\title{
A New and Improved Automated Technology for Early Sex Determination of Ginkgo biloba
}

\author{
Vincent Echenard, François Lefort, Gautier Calmin, Robert Perroulaz, and Lassaad Belhahri
}

\begin{abstract}
Random amplified polymorphic DNA (RAPD) technique with male associated decamer primer S1478 was used to amplify DNA from 72 leaf samples collected from Ginkgo biloba trees with known sexual determinism in the canton of Geneva, Switzerland. This marker was found to be male-specific and was lacking in all female plants. Automated random polymorphic DNA analysis (ARPA), a new automated technology developed in the frame of this work, proved highly effective in distinguishing males and females with $100 \%$ efficiency and successful in male and female discrimination from a collection of young seedlings derived from a sexual cross. Our findings provide unambiguous evidence that ARPA combined with the male-associated decamer primer S1478 could be considered an efficient, rapid, and easy method to make an early sex determination in the dioecious tree Ginkgo biloba.
\end{abstract}

The maidenhair tree Ginkgo biloba is a widely popular deciduous and dioecious gymnosperm species that is native to China and has been cultivated for well over a millennium. Ginkgo biloba has been described as a "living fossil" because it is known to have existed early in the Jurassic period and is believed to be the sole survivor of the ancient family of Ginkgoaceae (Carrier et al. 1998; Zhou and Zheng 2003). In Asia, G. biloba is used in traditional medicine and its seeds, also known as Ginkgo nuts, are considered a delicacy and are also a popular cuisine item (Kiple and Ornelas 2000). Asian people systematically planted the tree and many living ginkgoes are known to be more than five centuries old in China and for approximately 1,000 years in Japan. Ginkgo was introduced to Europe in the 18th century where it was very popular in large cities like London and Paris (Rohr 1989). The oldest European ginkgo would have been sown in 1730 in the Utrecht Botanical Garden. Most of the earlier trees raised in Europe appear to have been males. The first recorded female tree was found in Bourdigny near Geneva in 1814 of which scions were grafted on a male tree in the Botanic garden of Montpellier where the first perfect seed has grown (Michel 1985).

G. biloba had an ability to survive pests, drought, storms, ice, and city soils (Aoki 1997; Handa et al. 1997; Honda 1997; Kim et al. 1997). Because it does not have invasive roots and requires minimum maintenance, it could be the perfect urban tree with a large potential planting range in temperate and subtropical climates in both hemispheres. The ginkgo is dioecious. That simply means that there are separate male and female plants (Laurain 2000). Female trees produce seeds that emit a noxious, foul odor on falling to the ground. The smell's description ranges from "rancid butter" to "vomit" and therefore female trees are considered to be undesirable (Wada and Haga 1997). The slippery pulp can also be a liability. These features caused city governments to actually remove and ban the female from being planted. Male ginkgoes do not produce a fruit and are selected as the main cultivars used to transplant in urban communities. This male cultivar of Ginkgo casts dense shade and the dense crown makes it suitable as a screen or noise buffer. It makes a durable street tree where there is enough overhead vertical space to accommodate the large size.

The availability of male and female associated random amplified polymorphic DNA (RAPD) markers such as the decamer primer S1478 (Jiang et al. 2003) prompted us to validate a reliable marker by testing it over a large collection of trees in the Canton of Geneva that originates from China as well as Japan. Jiang et al. (2003) screened 1200 random decamers, which generated 8,372 RAPD primers among which they found two malelinked markers RAPD markers. One of these markers, S1478, was validated for sex determination in Ginkgo trees from two Chinese regions The need for a more rapid and reproducible method of early sexual determinism in $G$. biloba led us to develop an automated version of RAPD, which previously relied on manual agarose gel electrophoresis and DNA detection by ethidium bromide staining. Automated random polymorphic DNA analysis (ARPA) has several advantages over the former method, thus increasing its usefulness as a technique for assessing the sexual determinism in G. biloba. The new method was found to be highly reproducible at all levels of replication tested. In this study, a capillary electrophoresis system was used to resolve large (up to $682 \mathrm{bp}$ ) ARPA-polymerase chain reaction size fragments from plant genomic DNA, representing a new application for this automated system. Therefore, ARPA was shown to be an efficient, easy, and cost-effective means for processing a large collection of $G$. biloba seeds for early sex determination.

\section{MATERIALS AND METHODS}

\section{Plant Material}

A total of $72 \mathrm{G}$. biloba trees of identified sex collected from Geneva, Carouge, Chêne-Bougeries, Choulex, Cologny, Corsier, Grand-Lancy, Grand-Saconnex, Jussy, Meinier, Meyrin, Nyon, Onex, Petit-Lancy, Petit-Saconnex, Vandoeuvre (Canton, Geneva) were used in this study. These are trees planted in different streets in the listed localities (Figure 1) and were located before the flowering period. A picture of each tree was taken on four occasions in each season from 11 November 2006 


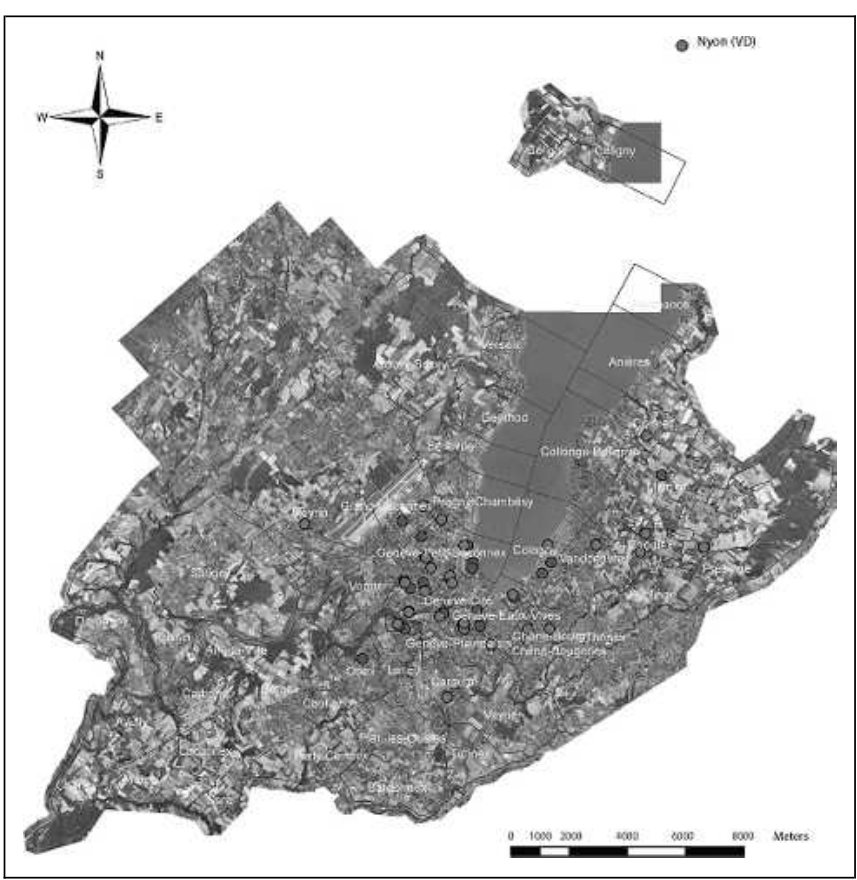

Figure 1. Distribution of the different regions in the Canton of Geneva on which $G$. biloba trees were sampled. Blue and rose spots refer, respectively, to male and female trees (1 km = $0.62 \mathrm{mi})$. until 7 September 2007 and compiled in a database. Trees were then checked during flowering for the sexual type of the flower (April 2007). Only trees for which the sex was determined without ambiguity were retained for leaf sampling, which took place in June 2007. GPS Swiss coordinates are given in Figure 2. Most trees are of Chinese origin, whereas five trees located in one park of Geneva City come from Japan. Plant material consisted of young leaves randomly sampled from the low branches of the low canopy of adult trees. Such a choice was determined by the difficulty to sample leaves on adult trees, which may be very tall. Three leaves were sampled per tree and kept frozen in nitrogen liquid until used. Seedlings of G. biloba used in this study were obtained from seeds collected from a female tree located in "Parc des Eaux-Vives" (Geneva, Satellite Swiss coordinates X: 501,956.004, Y: 118,199.472), which were sown in individual pots of horticultural substrate and then labeled for differentiating from one another.

\section{DNA Isolation}

DNA was purified from leaves with the use of the protocol described by Lefort and Douglas (1999) according to the manufacturer's specifications. Quality was checked by visualization under ultraviolet light after electrophoresis separation with a molecular mass standard (1 Kb Ladder Plus DNA Marker; Invitrogen, Basel, Switzerland) in 2\% agarose gel (Sigma, Buchs, Switzerland) in 1XTBE subjected to $100 \mathrm{~V}$ for $1 \mathrm{hr}$, and stained

Table 1. Sampled trees: sample number, sex based on flower morphology, circumference on 15 January 2007 , GPS coordinates, and sampling dates $(1 \mathrm{~m}=3.28 \mathrm{ft})$.

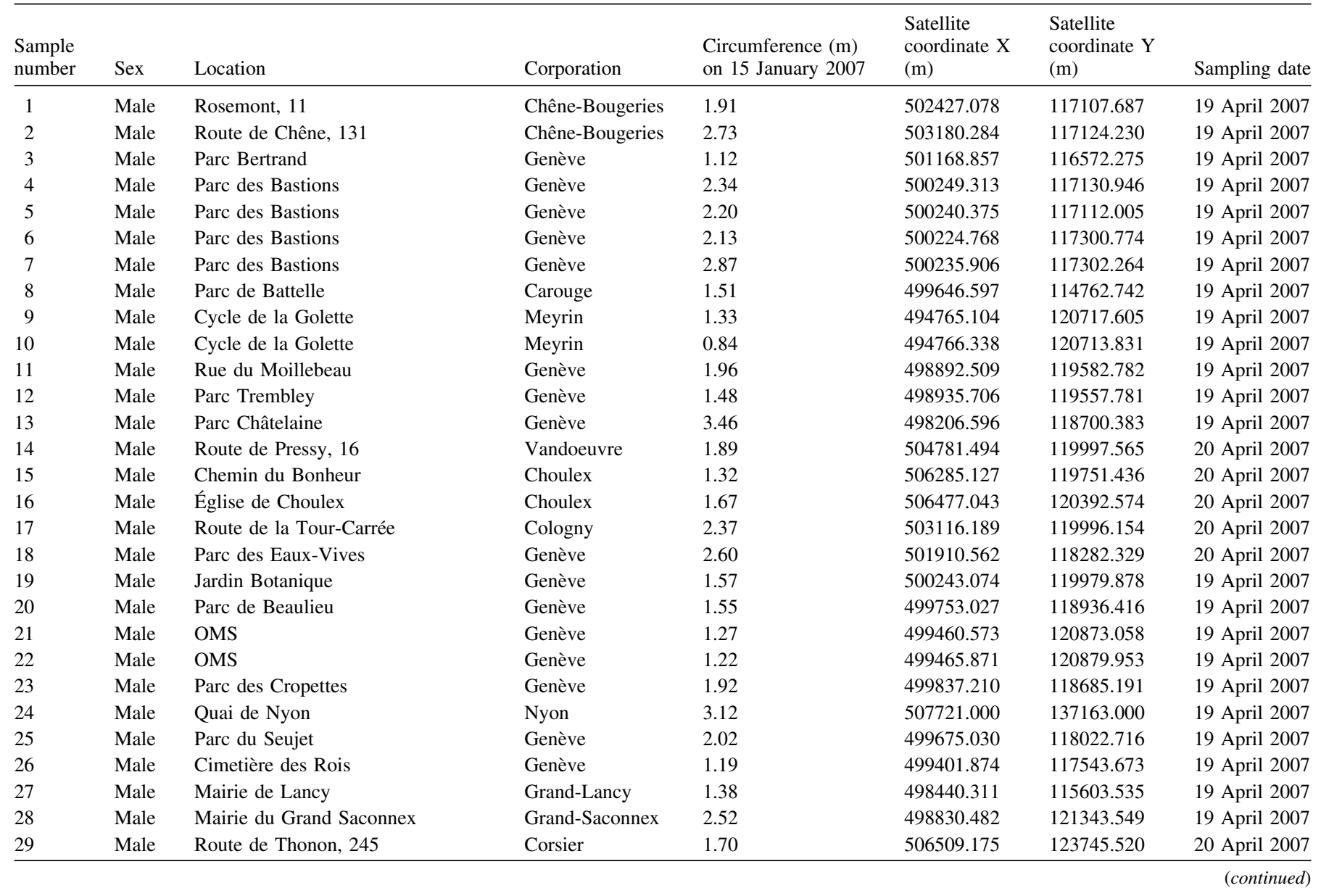


Table 1. (continued)

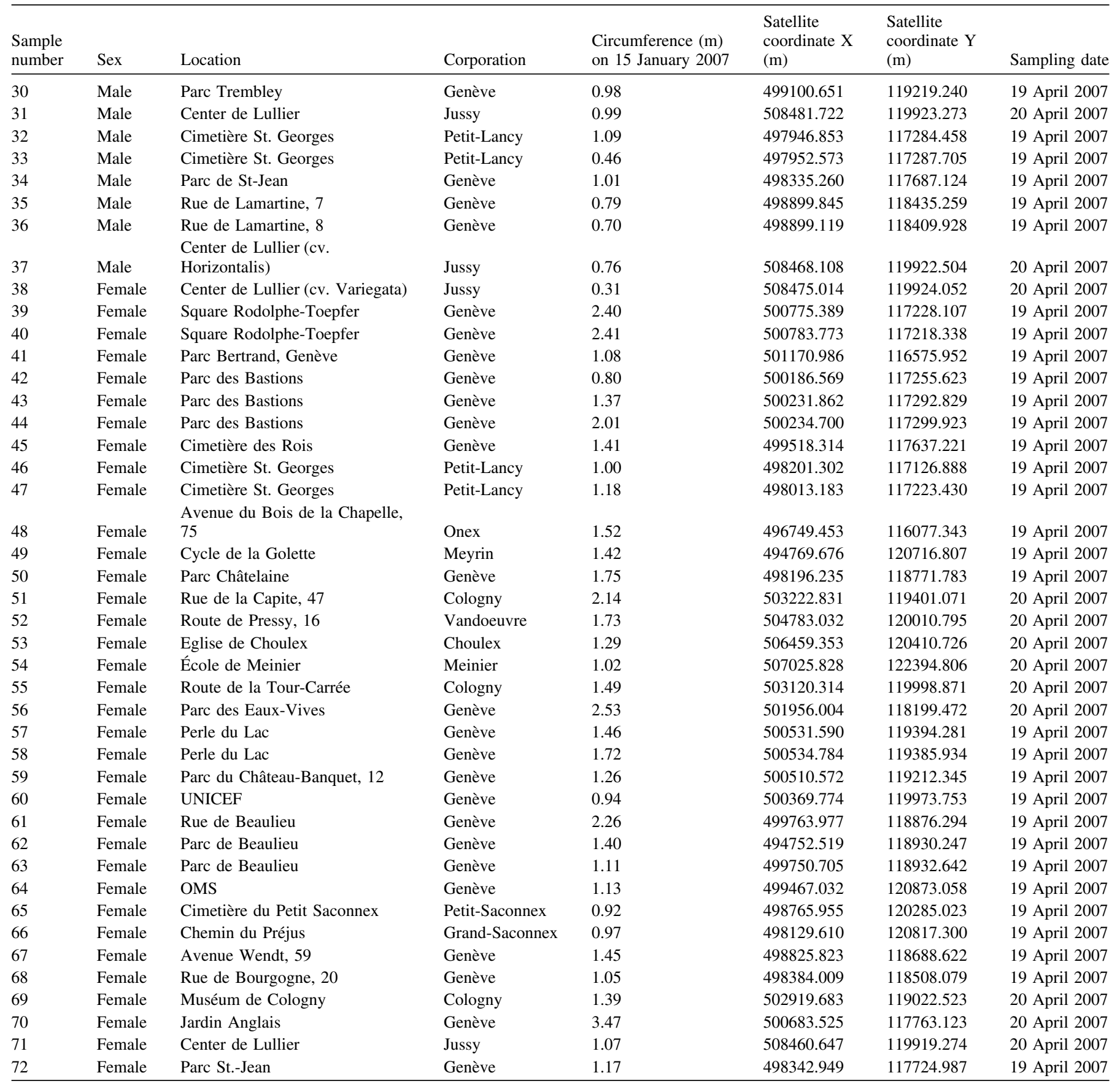

with Gel Red (Chemie Brunschwig AG, Basel, Switzerland) according to the manufacturer's recommendations. Concentrations were assayed with a NanoDrop ND-1000 ultraviolet spectrophotometer (Witec AG, Luzern, Switzerland). Performance of the different DNA samples used in this study in polymerase chain reaction (PCR) amplification have validated using the Ginkgo male and female primers VE-US-F ( $5^{\prime}$ CTG GTG CTG ATG ATC ATG CCA AAT GGT G 3') and VE-US-R (5' CTG GTG CTG AGA ACT ACC TCT TTA TTC CAT GC $3^{\prime}$ ). All DNA samples proved successful in PCR amplification with the expected size of the amplicon (data not shown).
Primers and Polymerase Chain Reaction Assays

RAPD amplifications of Ginkgo DNA leaf samples were carried out using previously described RAPD male-associated marker S1478 (Jiang et al. 2003). The reaction mixture contained $1 \times$ PCR buffer (75 mM Tris-HCl [pH 9.0], $50 \mathrm{mM} \mathrm{KCl,} 20 \mathrm{mM}$ [NH4]2SO4), $0.1 \mathrm{mM}$ dNTPs, $0.25 \mathrm{mM}$ of the primer S1478, $1.5 \mathrm{mM} \mathrm{MgCl} 2,1 \mathrm{U}$ of Taq polymerase (Biotools, Madrid, Spain), and $1 \mu \mathrm{L}\left(35.10^{-6} \mathrm{fl} \mathrm{oz}\right)$ of leaf DNA in a total volume of $50 \mu \mathrm{L}\left(176.10^{-5} \mathrm{fl} \mathrm{oz}\right)$. Amplifications were carried out in a Master Gradient thermocycler (Eppendorf, Hamburg, Germany) according to the following amplification program: an initial de- 
naturation step of $95^{\circ} \mathrm{C}\left(203^{\circ} \mathrm{F}\right)$ for 5 min followed by 39 cycles including denaturation for $60 \mathrm{sec}$ at $94^{\circ} \mathrm{C}\left(201.2^{\circ} \mathrm{F}\right)$, annealing for $60 \mathrm{sec}$ at $40^{\circ} \mathrm{C}\left(104^{\circ} \mathrm{F}\right)$, and extension for $2 \mathrm{~min}$ at $72^{\circ} \mathrm{C}$ $\left(161.6^{\circ} \mathrm{F}\right)$. Amplification was terminated by a final extension step of $7 \mathrm{~min}$ at $72^{\circ} \mathrm{C}\left(161.6^{\circ} \mathrm{F}\right)$. Amplicons were checked by gel electrophoresis as previously described.

\section{Automated Random Polymorphic DNA Analysis}

ARPA-PCR was performed following the method of Fisher and Triplett (1999) with few modifications. Reaction mixtures were as previously described. The primer used S1478, 5' CTGGTGCTGA 3' (male-associated decamer primer; Jiang et al. 2003) and was $5^{\prime}$ end labeled with the phosphoramidite dye 5-FAM. Labeled PCR products have then been analyzed according to Fisher and Triplett (1999) by Microsynth GMBH (Balgach, Switzerland). The data were analyzed by using the GeneMarker software program (Soft Genetics distributed by GATC Biotech AG., Konstanz, Germany). The program output is a series of peaks (an electropherogram), the sizes of which are estimated by comparison to fragments in the internal size standard (GeneScan ${ }^{\circledR}-1000$ $[\mathrm{ROX}]^{\mathrm{TM}}$, Applied Biosystems, Rotkreuz, Switzerland).

\section{Random Amplified Polymorphic DNA Amplicon Cloning}

RAPD PCR products were cloned using the TOPO cloning kit (Invitrogen, Basel, Switzerland) and sequenced directly in both sense and antisense directions (Fasteris SA, Geneva, Switzerland). All isolates were sequenced twice and a consensus sequence was created from the duplicates. DNA sequences have been deposited in GenBank (Bethesda, MD) (FI136224, FI136225). DNA sequence of the other recovered amplicons that are common to males and females have been also registered under the accession numbers (FI136226, FI136227).

\section{RESULTS}

\section{Validation of Decamer Primer S1478 as Male-Associated}

To test if the S1478 male-associated RAPD marker could be reliably used for sex determination in G. biloba, 72 trees with known sexual determinism (37 male trees and 35 female trees) have been identified all around the Canton of Geneva territory (Figure 3) and leaf samples ere collected from these trees in June 2007. Sexual determinism has been verified in individual trees in the flowering season to confirm the sex in individual trees. Amplification reactions carried out with DNA from ten male and ten female plants (originating from China) and using the decamer primer S1478 showed an approximately 680 bp sized band that was present in males and absent from all females tested (Figure 3).

This step was followed by applying the method to the remaining 62 trees (Figure 4) and discriminated male and females. The sexualities of $G$. biloba trees deduced from the RAPD reactions were identical to the collector's records. The sex marker S1478$680 \mathrm{bp}$ could be used to reliably detect the sexes of $\mathrm{G}$. biloba trees from different areas and geographic origins because it amplified in samples from both origin, China and Japan.

\section{S1478 Male-Associated Polymerase Chain Reaction Amplicon Cloning and Sequencing} PCR products originating from RAPD amplifications with four male and female trees were purified and cloned into the pCR2.1 vector. Positive colonies were selected according to the electrophoretic mobility of the inserted fragment. For this purpose, PCRs with the selective primers were conducted using the colonies as a template. The mobility of the PCR product was compared with the corresponding RAPD fragment on the RAPD gel. At least two clones were selected and sequenced for each sexlinked RAPD marker. The sequence of the male-specific amplicons (682 bp in length) analyzed using Blast program (National
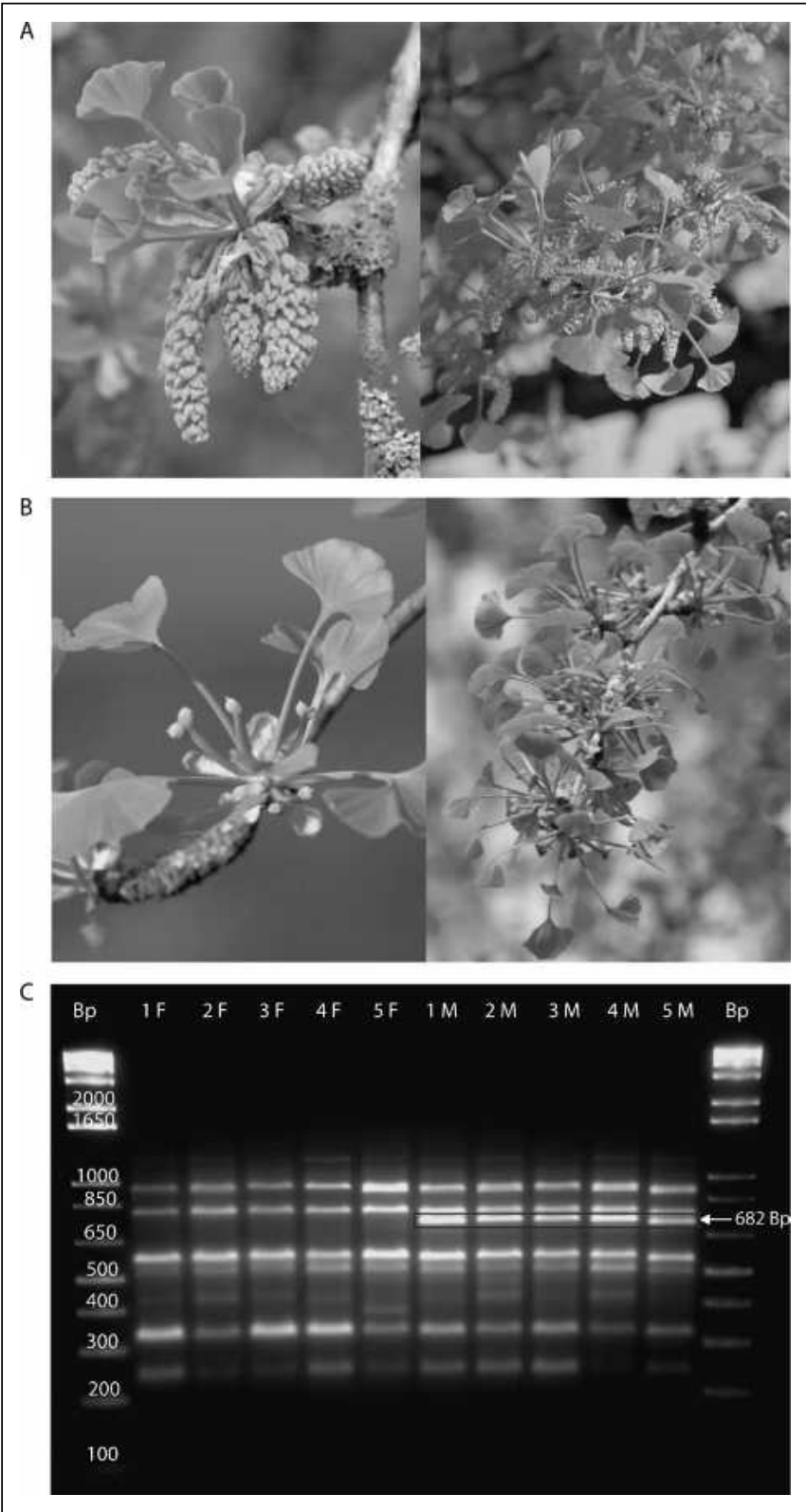

Figure 3. Morphologic and molecular differences between male and female $G$. biloba trees. (A) Male inflorescences. (B) Female inflorescences. (C) Random amplified polymorphic DNA (RAPD) pattern of male and female trees generated by primer S1478. Lane Bp, molecular weight marker; lanes IF-5F, RAPD products from DNA of female plants collected from the city of Geneva; lanes 1M-5M, RAPD products from DNA of male plants collected from Chêne-Bougeries and Geneva. Arrowhead indicates male-related marker. 


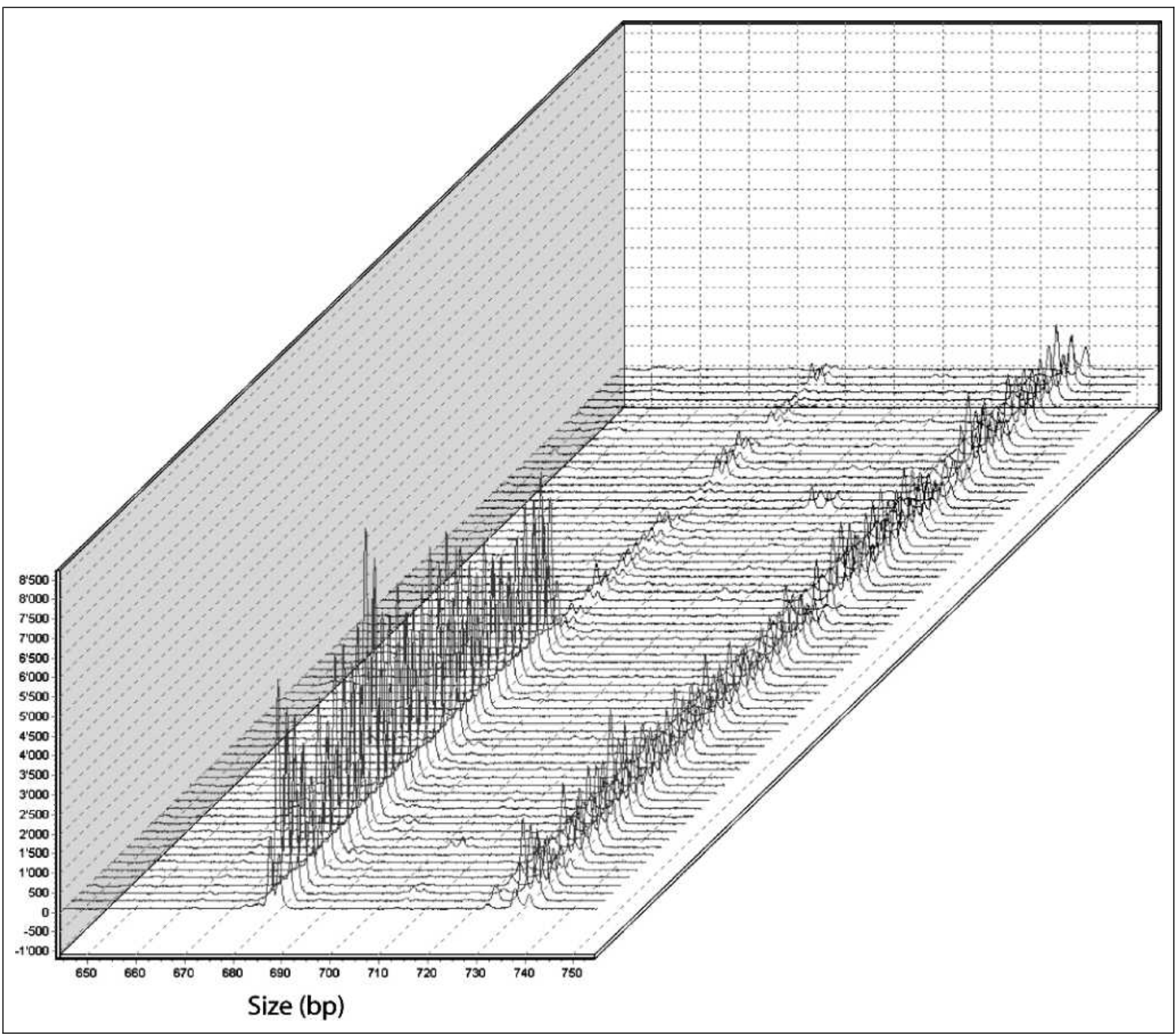

Figure 4. Automated random polymorphic DNA analysis profiles of male and female plants. Blue and rose pics refer, respectively, to male and female plants.

Center for Biotechnology Information, Bethesda, MD) showed no hits to any known sequence in the database.

\section{Automated Random Polymorphic DNA Analysis Development}

ARPA-PCR has been thought as a new application following the method of Fisher and Triplett (1999). We used a male-associated decamer primer S1478, 5' CTGGTGCTGA 3' (Jiang et al. 2003), which was $5^{\prime}$ end labeled with the phosphoramidite dye 5-FAM. Sample fragments were then discriminated by using the ABI 310 genetic analyzer (Perkin-Elmer, Waltham, MA), in which DNA is submitted to electrophoresis in a capillary tube filled with electrophoresis polymer rather than in a polyacrylamide gel. The samples were run under standard ABI 310 denaturing electrophoresis conditions for $1 \mathrm{hr}$ each with the POP-4 polymer, and the data were analyzed by using the GeneScan 3.1 software program (Perkin-Elmer). Figure 4 shows successful analysis of sexual determinism in analyzed plants. As a result of the higher resolution of ARPA, the male-specific fragment was sized at682 bp, whereas the fragment common to males and females displayed a length of $734 \mathrm{bp}$.

\section{Automated Random Polymorphic DNA Analysis Performance on Seedlings Derived from a Sexual Cross}

ARPA was used to assess the sexual determinism of a set of 21 2-year-old seedlings derived from seeds collected from a female tree. Initial experiments included testing of DNA performance in PCR using primers that perform well on male and female plants. This experiment showed an amplicon with expected accurate size. This control is thought to rule out false-negatives as a result of poor DNA quality. This analysis showed ten seedlings dis- 
playing the male-specific amplified DNA fragment and 11 seedlings not displaying this male-specific fragment. These 11 seedlings are then considered female trees by inference from the molecular sexing results on adult trees. Three to four PCR replicates were performed yielding identical results for each sample. The ARPA profiles (electropherograms) for PCRs from this collection of seedlings (Figure 5) were highly reproducible as evidenced by the fact that the electropherograms representing the duplicate PCRs for the collection of seedlings are almost entirely overlapping (data not shown).

\section{DISCUSSION}

Several techniques were used to distinguish between male and female trees in G. biloba, including biochemical tests (Zhong et al. 1982). Later, these biochemical differences have been shown to be related to age and growth situation of trees (Jiang et al. 2003). Recently, Jiang et al. (2003) succeeded in distinguishing between male and female trees by a reliable RAPD-PCR approach using the male-specific RAPD marker S1478. This study aimed at validating $\mathrm{S} 1478$ as a male-associated marker in $G$. biloba. Using a large collection of male and female trees collected from the Canton of Geneva and that originated from China and Japan, we could provide strong evidence that this marker could reliably be used in this task.

The results obtained with ARPA should be cautiously interpreted. As a molecular technique that relies on total DNA extraction and PCR amplification, ARPA is subject to the usual problems associated with DNA quality for performance in PCR.

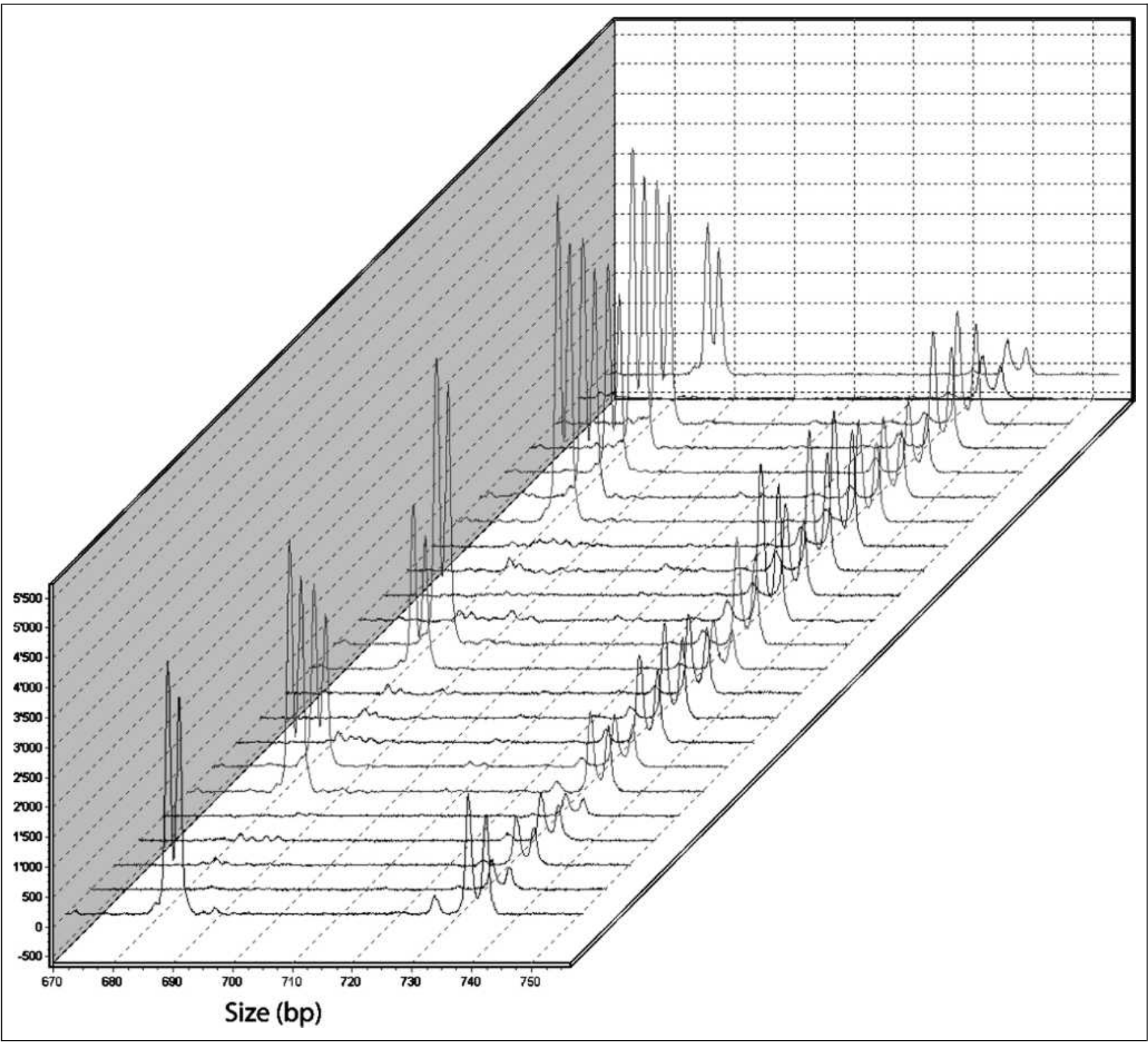

Figure 5. Automated random polymorphic DNA analysis profiles of male and female seedlings derived from a sexual cross. Blue and rose peaks refer, respectively, to male and female plants. Deep blue and red colors of peaks refer, respectively, to a previously identified male and female trees used as controls. 
For these reasons, any conclusions regarding sexual determinism using ARPA profiles should be carefully made. Use of appropriate controls such as those used in this study allows accurate conclusions regarding sexual determinism to be correctly drawn.

Male plants could now be selected from seedlings issued from seeds. Decreasing prices in molecular biology consumables and technologies would result in affordable sexing services for larger numbers of plants at an early stage. Growing male plants in nurseries instead of a mix of both sexes will optimize the use of nursery surfaces and then contribute to lower the price of such trees, which on the other hand could be more desirable as urban trees once male-certified. Consequently, sexual reproduction and sewing of Ginkgo seeds could benefit this technique and allow the availability of a greater diversity in urban Ginkgo trees.

Early sexual determination gained from ARPA allows for effective selection of male Ginkgo biloba trees highly suited by city governments for planting in streets and allows practitioners to easily provide such plants with no need to grow female plants for over 30 years.

Acknowledgments. Special thanks go to Georges Wigger (Microsynth, Balgach, Switzerland) for providing helpful advice about ARPA. We are also grateful to Nicolas Hasler (Domaine Nature et Paysage, Département du Territoire, Republic of Geneva) and Yves Fessler (Service des Espaces Verts of Geneva Town Hall) for authorizing sampling of $G$. biloba trees. Dominique Verdel, Centre d'Enseignement Professionnel Nature et Paysage, is acknowledged for his stimulating discussions and advice during the conduction of this work.

\section{LITERATURE CITED}

Aoki, T. 1997. Fungal association with Ginkgo biloba, p. 251-258. In: Hori, T., P. Del Tredici, R.W. Ridge, W. Tulecke, J. TremouillauxGuiller, and H. Tobe (Eds.). Ginkgo biloba-A Global Treasure. Springer-Verlag, Tokyo, Japan.

Carrier, D.J., T.A. van Beek, R. van der Heijden, and R. Verpoorte. 1998. Distribution of ginkgolides and terpenoid biosynthetic activity in Ginkgo biloba. Phytochemistry 48:89-92.

Fisher, M.M., and E.W. Triplett. 1999. Automated approach for ribosomal intergenic spacer analysis of microbial diversity and its application to freshwater bacterial communities. Applied and Environmental Microbiology 65:4630-4636.

Handa, M., Y. Lizuka, and N. Fujiwara. 1997. Ginkgo landscapes, p. 259-283. In: Hori, T., P. Del Tredici, R.W. Ridge, W. Tulecke, J. Tremouillaux-Guiller, and H. Tobe (Eds.). Ginkgo biloba-A Global Treasure. Springer-Verlag, Tokyo, Japan.

Honda, H. 1997. Ginkgo and insects, p. 259-283. In: Hori, T., P. Del Tredici, R.W. Ridge, W. Tulecke, J. Tremouillaux-Guiller, and H. Tobe (Eds.). Ginkgo biloba-A Global Treasure. Springer-Verlag, Tokyo, Japan.

Jiang, L., R.L. You, M.X. Li, and C. Shi. 2003. Identification of a sex associated RAPD marker in Ginkgo biloba. Acta Botanica Sinica 45:742-747.

Kim, Y.S., J.K. Lee, and G.C. Chung. 1997. Tolerance and susceptibility of Ginkgo to air pollution, p. 233-242. In: Hori, T., P. Del Tredici, R.W. Ridge, W. Tulecke, J. Tremouillaux-Guiller, and H. Tobe (Eds.). Ginkgo biloba-A Global Treasure. Springer-Verlag, Tokyo, Japan.

Kiple, K.F., and K.C. Ornelas. 2000. The Cambridge World History of Food. Cambridge University Press, Cambridge, U.K. 1958 pp.

Laurain, D. 2000. Cultivation of Ginkgo biloba on large scale, p. 63-79. In: Van Beek, T.A. (Ed.). Ginkgo biloba. Harwood Academic Publishers, Amsterdam, The Netherlands.

Lefort, F., and G.C. Douglas. 1999. An efficient micro-method of DNA isolation from mature leaves of four hardwood tree species Acer, Fraxinus, Prunus and Quercus. Annals of Science 56:259-263.
Michel, P.F. 1985. Ginkgo biloba: L'arbre qui a vaincu le temps. Editions du Félin, Paris. 108 pp.

Rohr, R. 1989. Maidenhair tree (Ginkgo biloba L.), p. 574-590. In: Bajaj, Y.P.S. (Ed.). Biotechnology in Agriculture and Forestry, Trees II. Springer Verlag, Berlin, Germany.

Wada, K., and M. Haga. 1997. Food poisoning by Ginkgo biloba seeds, p. 309-321. In: Hori, T., P. Del Tredici, R.W. Ridge, W. Tulecke, J. Tremouillaux-Guiller, and H. Tobe (Eds.). Ginkgo biloba-A Global Treasure. Springer-Verlag, Tokyo, Japan.

Zhong, H.W., Z.H. Yang, G.L. Zhu, and Z.X. Cao. 1982. Peroxidase isozyme pattern as a biochemical test to distinguish the sex of individual plant in Ginkgo biloba L. Scientia Silvae Sinica 18:1-5.

Zhou, Z.Y., and S.L. Zheng. 2003. Palaeobiology: The missing link in Ginkgo evolution-The modern maidenhair tree has barely changed since the days of the dinosaurs. Nature 423:821-822.

Vincent Echenard

University of Applied Sciences of Western Switzerland

Plants and Pathogens Group

Research Institute Earth, Nature and Landscape

150 route de Presinge Jussy

Geneva 1254, Switzerland

François Lefort (corresponding author)

University of Applied Sciences of Western Switzerland

Plants and Pathogens Group

Research Institute Earth, Nature and Landscape

150 route de Presinge Jussy

Geneva 1254, Switzerland

francois.lefort@hesge.ch

Gautier Calmin

University of Applied Sciences of Western Switzerland

Plants and Pathogens Group

Research Institute Earth, Nature and Landscape

50 route de Presinge Jussy

Geneva 1254, Switzerland

Robert Perroulaz

University of Applied Sciences of Western Switzerland

Agronomy Department

Geneva 1254, Switzerland

Lassaad Belbahri

University of Applied Sciences of Western Switzerland

Plants and Pathogens Group

Research Institute Earth, Nature and Landscape

50 route de Presinge Jussy

Geneva 1254, Switzerland

Résumé. Une technique d'amplification polymorphique aléatoire d'ADN du gène S1478 associé au sexe mâle a été utilisée pour amplifier l'ADN de 72 échantillons de feuilles récoltés à partir de Ginkgo biloba dont le sexe était connu dans le canton de Genève en Suisse. Ce marqueur a été a été découvert comme étant spécifique au mâle et est absent de tous les plants femelles. L'analyse polymorphique aléatoire d'ADN automatisée, une nouvelle technologie d'automatisation développée dans ce but, s'est avérée être hautement effective pour distinguer les plants mâles des plants femelles, et ce à $100 \%$ d'efficacité et de succès dans la discrimination mâle versus femelle au sein d'une collection de jeunes semis obtenus à partir de croisements sexuels. Nos découvertes fournissent une preuve sans ambiguïté que l'analyse polymorphique 
d'ADN combinée avec le gène $\mathrm{S} 1478$ peut être considérée comme une méthode efficace, rapide et facile pour déterminer dans les premiers stades le sexe de l'arbre dioïque Ginkgo biloba.

Zusammenfassung. Im Kanton von Genf, Schweiz, wurde von 72 Blattsammlungen von Ginkgo biloba mit bekannter sexueller Bestimmung zur Erweiterung ihrer DNS die zufällige, erweiterte, polymorphe DNS-Technik (RAPD) mit S1478 angewendet. Dieser Marker (S1478) ist männchen-spezifisch und fehlt in allen weiblichen Pflanzen. Automatische, randomisierte, polymorphe DNS-Analysen (ARPA), eine eigens im Rahmen dieser Arbeit entwickelte Technologie, zeigte sich als sehr effektiv in der Unterscheidung männlicher und weiblicher Pflanzen (100\%) und erfolgreich bei der Unterscheidung männlicher und weiblicher Sämlinge, die aus einer sexuellen Kreuzung entstanden sind. Unsere Ergebnisse liefern den unstrittigen Beweis, dass ARPA, kombiniert mit S1478 als eine effiziente, schnelle und einfache Methode bei der
Geschlechtsbestimmung bei Ginkgo biloba in Betracht gezogen werden kann.

Resumen. Se empleó la técnica polimórfica al azar amplificada DNA (RAPD), con plantas masculinas asociadas S1478, para amplificar DNA de 72 muestras de hojas colectadas de árboles de Ginkgo biloba con determinismo sexual conocido en el cantón de Ginebra, Suiza. Se encontró que este marcador es específico para masculinos y no se encontró en plantas femeninas. El análisis polimórfico (ARPA), una nueva tecnología desarrollada en la estructura de este trabajo, probó altamente su efectividad para distinguir masculinos y femeninos con $100 \%$ de eficiencia y éxito en la discriminación de masculinos y femeninos de una colección de brinzales derivados de una cruza sexual. Nuestros hallazgos proveen evidencia inequívoca de que ARPA, combinada con el S1478, podría ser considerado un método eficiente, rápido y fácil para hacer una determinación sexual en árboles deciduos de Ginkgo biloba. 